\title{
Arbeidsvermogensschade van jonge kinderen
}

\author{
Naar een nieuwe wijze van schadeberekening vanuit het perspectief van \\ gelijkebehandelingswetgeving
}

\author{
$M r . I . K a r i m i *$
}

\begin{abstract}
1. Inleiding
In het letselschaderecht is de wijze van schadeberekening voor het verlies van arbeidsvermogen de laatste jaren steeds meer aan kritiek onderhevig. Al geruime tijd staat ter discussie of de positie van jonge letselslachtoffers een alternatieve wijze van schadeberekening rechtvaardigt. Ter onderbouwing van dergelijke hervormingen wordt een aantal argumenten aangevoerd. Allereerst is de vaststelling van de hypothetische situatie bij jonge kinderen zeer lastig en (te) speculatief. ${ }^{1}$ Daarnaast zet de huidige wijze van schadeberekening aan tot vele discussies tussen procespartijen, hetgeen het procesverloop niet ten goede komt. ${ }^{2}$ Thans wordt de berekeningswijze echter ook op een ander punt bekritiseerd. De uitspraak van de Rechtbank Den Haag van 23 juli 2013 laat zien dat het huidige schadevergoe-
\end{abstract}

Mr. I. Karimi heeft in 2017 de master Privaatrecht afgerond aan de Universiteit Utrecht. Aansluitend aan haar afstuderen is ze als juridisch medewerker in dienst getreden bij Asselbergs \& Klinkhamer Advocaten. Dit artikel is gebaseerd op de masterscriptie van de auteur. Hiervoor heeft zij drie scriptieprijzen mogen ontvangen, namelijk die van het Juridisch Bureau Letselschade en Gezondheidsrecht, van het Molengraaff Instituut en die van de Stichting Beer Impuls.

De auteur dankt dr. mr. R. Rijnhout voor haar commentaar op deze bijdrage. Tevens is de auteur dank verschuldigd aan dr. mr. E.F.D. Engelhard voor haar commentaar op een eerdere versie. De auteur beoogt met dit artikel geen volledige en gedetailleerde analyse te geven van alle alternatieve wijzen van schadeberekening.

1. T. Hartlief, Prognoses in het personenschaderecht, AV\&S 2005/27, afl. 5, p. 163-165; T. Hartlief, Vergoeden van personenschade: wat is wijsheid?, in: A.G. Castermans e.a. (red.), Ex Libris Hans Nieuwenhuis, Deventer: Kluwer 2009, p. 525-526; S.D. Lindenbergh, Verzilveren van letselschade, wat betekent dat?, in: M. Faure (red.), De toekomst van de letselschadepraktijk: voordrachten gehouden op het symposion van de Vereniging van Letselschade Advocaten 2014, Den Haag: Sdu Uitgevers 2014, p. 2 (hierna: Lindenbergh 2014a); J.F.M. Janssen, De begroting van inkomensschade van baby's en peuters als gevolg van aan hen toegebracht ernstig hersenletsel, NTBR 2007/11, afl. 3, p. 110.

2. M.Th. Beumers \& W.H. van Boom, De maatmens-benadeelde in het aansprakelijkheidsrecht, in: M.Th. Beumers, W.H. van Boom \& M.A. Loth, Aansprakelijkheidsrecht en maatmens, Deventer: Wolters Kluwer 2016, p. 17. dingsrecht ruimte laat voor verboden discriminatie. ${ }^{3}$ In deze deelgeschilprocedure besliste de rechtbank over de te hanteren uitgangspunten bij de vaststelling van de vermogensschade. In navolging van het door de verzekeraar geschetste scenario achtte de rechtbank het redelijk om te veronderstellen dat het slachtoffer na de geboorte van haar kinderen tien jaar niet zou hebben gewerkt en daarna slechts parttime zou werken. Volgens de rechtbank is het onvermijdelijk dat rekening wordt gehouden met de omstandigheid dat [het slachtoffer] een vrouw is, maar dit maakt nog niet dat de aannames daarmee discriminerend zijn'. ${ }^{4}$ Het College voor de Rechten van de Mens oordeelde daarentegen dat de verzekeraar bij de berekening van de omvang van de vermogensschade direct verboden onderscheid op grond van geslacht had gemaakt, in de zin van artikel 7 lid 1 sub a van de Algemene wet gelijke behandeling (AWGB). ${ }^{5}$ Het College vond het niet aannemelijk dat de verzekeraar de geformuleerde uitgangspunten op eenzelfde wijze zou toepassen bij de berekening van het verlies van het verdienvermogen van een man. ${ }^{6}$

Dat ongelijke behandeling bij de schadeberekening mogelijk is, is in wezen een logische uitwerking van het Nederlandse schadevergoedingsrecht. Het beginsel van concrete schadebegroting zet de rechter ertoe aan om bij de vaststelling van toekomstschade rekening te houden met alle persoonlijke ken-

3. Rb. Den Haag 23 juli 2013, ECLI:NL:RBDHA:2013:9276, L\&S 2013/213 m.nt. R.A. Hebly, JA 2013/171 m.nt. Dute. Voor een uitgebreide analyse van deze zaak, zie o.a. J.M. Emaus, Verboden onderscheid op grond van geslacht bij de vaststelling van de hoogte van de letselschadevergoeding: blik op Canada, L\&S 2015/3, afl. 3, p. 6-23; E.S. Engelhard, M.R. Hebly \& S.D. Lindenbergh, Gelijkheidsperikelen in het personenschaderecht, NTBR 2015/39, afl. 9, p. 257-265; Chr.H. van Dijk, Statistiek, verboden onderscheid tussen mannen en vrouwen en concrete schadeberekening, AV\&S 2015/19, afl. 4, p. 114-125; N. Benaissa, Discriminatie in de Nederlands letselschadepraktijk: het topje van de ijsberg, TLP 2015/110, afl. 5, p. 30 e.v.; M.A. Loth, Schadebegroting en mensenrechten, AV\&S 2014/17, afl. 5-6, p. 117-118.

4. Rb. Den Haag 23 juli 2013, L\&S 2013/213 m.nt. R.A. Hebly, JA 2013/171 m.nt. Dute, r.o. 4.11.

5. CRM 19 augustus $2014,2014-97$, r.o. 3.11 .

6. CRM 19 augustus 2014, 2014-97, r.o. 3.11. 
merken van de benadeelde. ${ }^{7}$ De rechter is echter niet alleen gehouden om de Nederlandse schadevergoedingsregels na te leven, hij zal zich ook rekenschap moeten geven van gelijkebehandelingswetgeving. In de Grondwet (Gw) en Europese wetgeving is het verboden om onderscheid te maken ten aanzien van bepaalde persoonlijke eigenschappen van slachtoffers. Eerder betoogde Emaus dat Richtlijn 2004/113/EG ${ }^{8}$ en de AWGB voldoende waarborgen bieden om ongelijke behandeling tussen mannen en vrouwen tegen te gaan bij de schadebegroting van verlies van arbeidsvermogen. ${ }^{9} \mathrm{Zij}$ analyseert zeven alternatieve benaderingen uit de Canadese rechtspraak en literatuur. De focus van haar onderzoek ligt bij alternatieve benaderingen die gelijke behandeling van man en vrouw bevorderen. Het huidige recht laat echter ook ruimte open voor verboden onderscheid op grond van andere gronden. Hoe kan worden voorkomen dat er direct dan wel indirect rekening wordt gehouden met bijvoorbeeld de etniciteit van het slachtoffer? Het gevaar van discriminatie bij de vaststelling van toekomstige schade is vooral bij jonge kinderen groot. $\mathrm{Bij}$ deze groep slachtoffers ontbreken veelal concrete gegevens aan de hand waarvan het hypothetische arbeidsvermogen kan worden vastgesteld. De rechter zal in dat geval eerder geneigd zijn om aannames te maken die gebaseerd zijn op stereotypen. Ook zal bij deze groep eerder gebruik worden gemaakt van statistische gegevens. In deze statistieken kunnen persoonlijke kenmerken verborgen liggen, op basis waarvan het verboden is om onderscheid te maken. In deze bijdrage zal ik ingaan op de vraag of voor jonge kinderen met ernstig letsel een afwijkende benadering voor verlies van arbeidsvermogen aangewezen is.

Dit artikel is als volgt opgebouwd. Allereerst schets ik het juridische kader aan de hand waarvan het verlies van arbeidsvermogen in Nederland wordt vastgesteld (par. 2). Vervolgens zet ik uiteen welke knelpunten in het huidige systeem van schadeberekening aanwezig zijn (par. 3 en 4). Daarna wordt het vizier gericht op alternatieve benaderingen voor de bepaling van toekomstschade (par. 5). Bij de evaluatie van deze benaderingen zal ik toetsen of de alternatieve modellen de huidige bezwaren van concrete schadebegroting kunnen wegnemen (par. 6). Omdat deze benaderingen waarschijnlijk ook hun eigen bezwaren kennen, zal ik tevens nagaan of daar oplossingen voor kunnen worden gevonden. Ten slotte zal ik afronden met een conclusie (par. 7).

\section{Het huidige recht}

In Nederland geldt het uitgangspunt van volledige schadevergoeding. Ter vaststelling van de omvang van de schadevergoeding dient een vergelijking te worden gemaakt tussen twee situaties: de feitelijke situatie waarin het slachtoffer zich bevindt ná het ongeval, en de hypothetische situatie waarin het slachtoffer zou hebben verkeerd als het ongeval niet had

\footnotetext{
7. Beumers \& Van Boom 2016, p. 15 en 19.

8. Richtlijn 2004/113/EG van de Raad houdende toepassing van het beginsel van gelijke behandeling van mannen en vrouwen bij de toegang tot en het aanbod van goederen en diensten.

9. Emaus 2015, p. 6-23.
}

plaatsgevonden. ${ }^{10}$ Beide situaties dienen te worden ingeschat, waarbij het 'aankomt op de redelijke verwachtingen van de rechter omtrent toekomstige ontwikkelingen'. ${ }^{11}$ Deze redelijke verwachtingen zullen veelal samenvallen met de realistische verwachtingen: de verwachtingen die, op basis van zo veel mogelijk concrete aanknopingspunten, overeenkomen met de voor deze benadeelde te verwachten 'normale gang van zaken'. ${ }^{12}$ Het tweede uitgangspunt van het schadevergoedingsrecht, te weten concrete schadeberekening, is een logisch uitvloeisel van het beginsel van volledige vergoeding. Dit uitgangspunt betekent dat rekening moet worden gehouden met alle relevante omstandigheden aan de kant van de benadeelde. ${ }^{13}$

De bewijslast ter zake van de omvang van het verlies van arbeidsvermogen rust, op grond van de hoofdregel van artikel 150 van het Wetboek van Burgerlijke Rechtsvordering (Rv), op de benadeelde. Het is aan hem om te schetsen hoe zijn levensloop eruit zou hebben gezien zonder de schadeveroorzakende gebeurtenis. Volgens de Hoge Raad mogen er geen hoge eisen worden gesteld aan het bewijs van deze hypothetische situatie. ${ }^{14}$ Het betreft immers een toekomst die het slachtoffer enkel aannemelijk kan maken, maar nooit zal kunnen bewijzen. De ratio achter deze slachtoffervriendelijke bewijsregel is dat de zekerheid omtrent hetgeen in die hypothetische situatie zou zijn voorgevallen, juist door de schadeveroorzakende gebeurtenis is ontnomen.

De rechter die de hypothetische toekomst moet vaststellen, dient een realistische inschatting te maken van de goede en kwade kansen van het slachtoffer. ${ }^{15}$ Bij deze inschatting krijgt de benadeelde het voordeel van de twijfel. Dit betekent echter niet dat het verlies van elke goede kans van het slachtoffer, hoe klein die ook is, volledig voor rekening van de aansprakelijke

10. Zie HR 15 mei 1998, ECLI:NL:HR:1998:ZC2654, NJ 1998/624 (Vehof/Helvetia); HR 13 december 2002, ECLI:NL:HR: 2002:AE9243, NJ 2003/212 (B./Olifiers); S.D. Lindenbergh \& I. van der Zalm, Schadevergoeding: personenschade, Deventer: Wolters Kluwer 2015, nr. 19-21.

11. Zie HR 15 mei 1998, ECLI:NL:HR:1998:ZC2654, NJ 1998/624 (Vehof/Helvetia); HR 13 december 2002, ECLI:NL:HR: 2002:AE9243, NJ 2003/212 (B./Olifiers).

12. Zie Hof Arnhem-Leeuwarden 5 augustus 2014, ECLI:NL:GHARL: 2014:6223, r.o. 2.5. De term 'normale gang van zaken' is geïntroduceerd door Hartlief (Hartlief 2005, p. 159-168) en wordt aangehaald in: Lindenbergh \& Van der Zalm 2015, nr. 21; G. de Groot \& A.J. Akkermans, Schadevaststelling, bewijslastverdeling en deskundigenbericht, NTBR 2007/72, p. 501-509; A.J. Akkermans, Wedden op een uit de race genomen paard: naar een bijzondere bewijsregel voor het bewijs van schade en causaliteit?, in: T. Hartlief \& S.D. Lindenbergh (red.), Tien pennenstreken over personenschade, Den Haag: Sdu Uitgevers 2009, p. 104; B. de Hek, Over dubbeltjes en kwartjes, in: A.J. Verheij \& A. Kolder (red.), Kwaliteit in het aansprakelijkheidsrecht, Den Haag: Boom juridisch 2016, p. 56.

13. S.D. Lindenbergh, Schadevergoeding: algemeen, deel 1, Deventer: Kluwer 2008, nr. 36; A.R. Bloembergen, Schadevergoeding bij onrechtmatige daad (diss. Utrecht), Deventer: Kluwer 1965, nr. 25.

14. HR 15 mei 1998, ECLI:NL:HR:1998:ZC2654, NJ 1998/624 (Vehof/ Helvetia), r.o. 3.5.2.

15. Beumers \& Van Boom 2016, p. 16; Lindenbergh \& Van der Zalm 2015, nr. 21. 
moet komen. ${ }^{16}$ Ook bij jonge kinderen zal de rechter aan de hand van concrete omstandigheden van het individu een inschatting moeten maken over de hypothetische situatie zonder ongeval. Doorgaans zullen concrete aanknopingspunten voor het carrièreverloop van deze groep slachtoffers ontbreken. Omdat de inschatting alsnog moet worden gemaakt, sluiten de rechters zich veelal aan bij de intelligentie en vaardigheden van het kind, het opleidingsniveau en de beroepsmogelijkheden van de familieleden van het kind, en ten slotte bij de maatschappelijke status van het gezin waarin het kind zich bevindt. ${ }^{17}$

\section{Knelpunten bij de huidige benadering}

In de literatuur wordt kritiek geuit op de huidige wijze van vaststelling van arbeidsvermogensschade. Het eerste knelpunt dat ervaren wordt in deze benadering is dat de inschatting van de hypothetische situatie zonder ongeval lastig en speculatief zou zijn. ${ }^{18}$ Dit geldt vooral waar het gaat om de toekomstige ontwikkelingen van jonge slachtoffers. Verschillende auteurs betogen dat deze benadering een aantal negatieve consequenties heeft. Deze berekeningswijze kan leiden tot zeer uiteenlopende schadevergoedingsbedragen in vergelijkbare gevallen, tot willekeur en tot onduidelijke en arbitraire beslissingen van rechters. ${ }^{19}$ Anders gezegd, het toepassen van de beginselen van volledige en concrete schadebegroting leidt bij jonge slachtoffers onvermijdelijk tot 'giswerk'. ${ }^{20}$ De vaststelling van arbeidsvermogensschade wordt dan ook beschouwd als een lastige taak met grote foutkansen. ${ }^{21}$

Het tweede probleem dat wordt genoemd, is dat de huidige berekeningswijze een vlotte en soepele afwikkeling van de schadeclaims in de weg staat. ${ }^{22}$ Over het algemeen zorgt de huidige wijze van schadeberekening voor discussies tussen het slachtoffer en de aansprakelijke, juist omdat het lastig is om concrete aanknopingspunten aan te wijzen die richtinggevend zijn voor de ontwikkeling van het kind als hij of zij geen ongeval zou hebben gehad. Omdat het huidige stelsel wel ruimte

16. HR 14 januari 2000, ECLI:NL:HR:2000:AA4277, NJ 2000/437 (Van Sas/Interpolis), r.o. 3.4.

17. S.C.P. Giesen \& R.P.J.L. Tjittes, De rekening van het kind - begroting van arbeidsvermogensschade en smartengeld bij jonge kinderen met blijvend ernstig letsel, in: S.D. Lindenbergh e.a. (red.), Schade: vergoeden of beperken?, Den Haag: Sdu Uitgevers 2004, p. 79.

18. Hartlief 2005, p. 163-165; 2009, p. 525-526; Lindenbergh 2014a, p. 2; Janssen 2007, p. 110.

19. Beumers \& Van Boom 2016, p. 17, met verwijzing naar Giesen \& Tjittes 2004, p. 73-74, 79-80 en 89; Hartlief 2005, p. 165-168; J.H. Nieuwenhuis, Wat is waarheid? Waarheidsvinding en privacy in het letselschaderecht, in: D.H.M. Peperkoorn (red.), Waarheidsvinding en privacy: inleidingen gehouden op het LSA-symposium 2005, Den Haag: Sdu Uitgevers 2005, p. 90-92; Janssen 2007, p. 100 en 102-104; Van Dijk 2015, par. 2.1.

20. Giesen \& Tjittes 2004, p. 80. In gelijke zin Janssen 2007, p. 110. Schadebegroting van jonge kinderen is volgens Janssen 'puur natte vingerwerk'.

21. Janssen 2007, p. 102-103. Reeds aangehaald door Beumers \& Van Boom 2016 (p. 17).

22. Beumers \& Van Boom 2016, p. 17. biedt voor partijen om hierover te discussiëren, vertraagt de afwikkeling van arbeidsvermogensschade. ${ }^{23}$

Het derde bezwaar tegen de wijze van schadeberekening is dat zij discriminatoir kan uitwerken. Engelhard en anderen hebben eerder uiteengezet wanneer concrete schadeberekening op gespannen voet komt te staan met gelijkebehandelingswetgeving. ${ }^{24}$ Dit spanningsveld ontstaat daar waar statistische gegevens handvatten aanreiken om aan de redelijke toekomstverwachtingen invulling te geven, maar waar diezelfde statistische gegevens duidelijk maken dat een bepaalde factor - bijvoorbeeld geslacht - een verschil in die verwachtingen met zich meebrengt. ${ }^{25}$ Worden de concrete verwachtingen ten aanzien van een individu gevormd op basis van bepaalde - voornamelijk aangeboren - kenmerken, dan levert dat ongeoorloofd onderscheid op. ${ }^{26}$ Wanneer onderscheid wordt gemaakt op basis van dergelijke kenmerken, is er sprake van schending van fundamentele rechtsbeginselen, waarmee rekening moet worden gehouden in het kader van de schadebegroting. De traditionele aanpak kan er dus toe leiden dat ongelijkheid in de maatschappij via het schadevergoedingsrecht wordt overgeplaatst naar de hypothetische situatie, waardoor die ongelijkheid bestendigd raakt. ${ }^{27}$ De vraag die zich dan voordoet, is of het schadevergoedingsrecht (in het kader waarvan het principe van restitutio in integrum het uitgangspunt is) wel de plek is om de maatschappelijke discussie over discriminatie te voeren. Deze vraag dient mijns inziens bevestigend te worden beantwoord. Het schadevergoedingsrecht wordt namelijk niet alleen aangestuurd door elementen van correctieve rechtvaardigheid, maar ook door die van distributieve rechtvaardigheid. $^{28}$

\section{Uitwerking van één knelpunt: discriminatieverbod}

In de Grondwet is een algemeen discriminatieverbod neergelegd. Dit beginsel is verder uitgewerkt in de AWGB en heeft tevens een sterk Europeesrechtelijke achtergrond. Dit beginsel wordt gewaarborgd in het EU-Handvest dat ingevolge artikel 6 van het Verdrag betreffende de Europese Unie qua rang en stand boven de verordeningen en richtlijnen staat. Dit brengt met zich mee dat de Nederlandse rechter toepassing moet geven aan het beginsel van gelijke behandeling als hij het

23. Aldus Beumers \& Van Boom 2016, p. 17, met verwijzing naar Hartlief 2005, p. 167; T. Hartlief, Recht doen met abstracte schadebegroting, NJB 2012/2463, afl. 43, p. 3007; Loth 2014; Van Dijk 2015, par. 6; Lindenbergh 2014a, p. 2-5 en 13.

24. Engelhard, Hebly \& Lindenbergh 2015.

25. Engelhard, Hebly \& Lindenbergh 2015, p. 260.

26. Engelhard, Hebly \& Lindenbergh 2015, p. 260

27. E. Adjin-Tettey, Replicating and perpetuating inequalities in personal injury claims through female-specific contingencies, McGill Law Journal 49 (2003), p. 309-348; Engelhard, Hebly \& Lindenbergh 2015, p. 263.

28. Distributieve rechtvaardigheid vereist een gelijke verdeling van goederen of lasten onder de leden van een groep of gemeenschap. Zie meer hierover Adjin-Tettey 2003, p. 343; M.A. Loth, Rechtvaardige aansprakelijkheid: over herstel van autonomie, beginselen in het ansprakelijkheidsrecht, en de 'maatmens benadeelde', Deventer: Wolters Kluwer 2016 (hierna: Loth 2016a). 
Unierecht ten uitvoer brengt. ${ }^{29}$ In artikel 1 AWGB staat dat het verboden is om onderscheid te maken op basis van de volgende persoonlijke kenmerken: godsdienst, levensovertuiging, politieke gezindheid, ras, geslacht, nationaliteit, hetero- of homoseksuele gerichtheid of burgerlijke staat. Het discriminatieverbod in artikel 1 AWGB geldt niet alleen voor de overheid, maar ook voor burgers onderling. ${ }^{30}$ Artikel 21 lid 1 EUHandvest formuleert het discriminatieverbod breder:

'Iedere discriminatie, met name op grond van geslacht, ras, kleur, etnische of sociale afkomst, genetische kenmerken, taal, godsdienst of overtuiging, politieke of andere denkbeelden, het behoren tot een nationale minderheid, vermogen, geboorte, een handicap, leeftijd of seksuele gerichtheid, is verboden.'

De positieve verplichtingen ${ }^{31}$ in het EU-Handvest zijn in de eerste plaats gericht aan de lidstaten. ${ }^{32} \mathrm{Wel}$ is het zo dat de beginselen in het EU-Handvest horizontale werking kunnen hebben, wanneer de specifieke bepaling een subjectief recht verleent aan particulieren. ${ }^{33}$ In de Kücükdeveci-zaak heeft het Hof van Justitie van de EU (hierna: Hof) bepaald dat aan discriminatie op grond van leeftijd in de zin van artikel $21 \mathrm{EU}$ Handvest rechtstreekse horizontale werking toekomt. ${ }^{34}$ Het Hof heeft zich nog niet uitgelaten over de overige discriminatiegronden in dit artikel, zodat onduidelijk is of deze ook horizontale werking hebben. Verschillende auteurs betogen dat de horizontale directe werking zoals aangenomen in het arrest Kücükdeveci niet enkel geldt voor het verbod op discriminatie op grond van leeftijd, maar óók voor andere discriminatieverboden die zijn genoemd in artikel 21 EU-Handvest. ${ }^{35}$

29. P. Craig \& G. de Búrca, EU law. Text, cases and materials, Oxford: Oxford University Press 2011, p. 109, reeds aangehaald door Emaus 2015, p. 15.

30. Bunschoten, in: T\&C Grondwet, commentaar op hoofdstuk $1 \mathrm{Gw}$, aant. 2. Via verschillende wetten is uitvoering gegeven aan het gelijkheidsbeginsel en het discriminatieverbod zoals neergelegd in art. $1 \mathrm{Gw}$. Deze wetten hebben horizontale werking. Zie voor de wetgeving die werkt tussen burgers onderling: https://www.mensenrechten.nl/gelijke behandelingswetgeving.

31. De leer van de positieve verplichtingen houdt in dat verdragsstaten hun verdragsverplichtingen niet enkel kunnen schenden door een 'doen', maar ook door een 'nalaten'. Volgens het Marckx-arrest (EHRM 13 juni 1979, 58442, NJ 1980/462 m.nt. E.A. Alkema, r.o. 13.) zijn verdragsstaten niet alleen verplicht om zich te onthouden van inbreuken op fundamentele rechten van individuen, maar kunnen zij onder het EVRM ook verplicht zijn om rechten te waarborgen.

32. Art. 51 lid $1 \mathrm{EU}-$ Handvest.

33. HvJ EU 15 januari 2014, C-176/12 (Association de médiation sociale), nr. 47.

34. HvJ EU 19 januari 2010, C-555/07 (Kücükdeveci).

35. M. de Mol, De directe werking van de grondrechten van de Europese Unie (diss. Maastricht), Oisterwijk: Wolf Legal Publishers 2014, p. 286; S. Prechal, Non-discrimination does not fall down from heaven, in: The context and evolution of non-discrimination in EU law (Eric Stein Working Paper No. 4/2009), 2009, p. 10; concl. A-G Jääskinen van 15 juli 2010, zaak C-147/08, Römer, punt 129.
Over de vraag of de familiale afkomst een grondslag vormt voor discriminatie, kan worden gediscussieerd. ${ }^{36}$ Deze factor wordt niet expliciet in artikel 1 AWGB genoemd. Het is wel mogelijk dat de familieachtergrond valt onder 'sociale afkomst' als bedoeld in artikel 21 lid 1 EU-Handvest. ${ }^{37}$ Het begrip sociale afkomst verwijst naar iemands geërfde sociale status. Dit betreft de positie die is verworven door geboorte 'in een bepaalde sociale klasse of gemeenschap (bijvoorbeeld gebaseerd op etniciteit, geloof of ideologie) of door een sociale situatie zoals armoede en dakloosheid' ${ }^{38}$ Volgens het bepaalde in artikel 21 EU-Handvest mag de sociaal-maatschappelijke status van een persoon geen beïnvloedende factor zijn. In Nederland brengt het beginsel van concrete schadebegroting met zich mee dat bij de vaststelling van de hypothetische situatie van een jong slachtoffer aansluiting kan worden gezocht bij de situatie van zijn ouders of broers en zussen. De sociale klasse waarin het kind zich bevindt, kan daarmee de hoogte van de schadevergoeding bepalen. Het voorgaande kan dan zo uitwerken dat de Nederlandse wijze van schadeberekening strijdig wordt bevonden met het Europees non-discriminatierecht. Als latere rechtspraak luidt dat het beginsel van non-discriminatie op grond van sociale afkomst horizontale werking heeft, zou het gebruik van de 'familiale afkomst' als factor bij de schadevaststelling mogelijk niet door de beugel kunnen. Het verdient mijns inziens de voorkeur dat de rechter hier bij voorbaat rekening mee houdt, door geen gebruik te maken van de familiale achtergrond van het slachtoffer.

\section{Alternatieve benaderingen}

\subsection{Introductie}

In deze paragraaf staat de vraag centraal of bij jonge kinderen met ernstig letsel een afwijkende berekeningswijze voor het verlies van verdienvermogen gerechtvaardigd is. In de Nederlandse literatuur bestaan verschillende stromingen. ${ }^{39}$ Een aantal auteurs meent dat het verlies van verdienvermogen ook bij jonge kinderen volledig moet worden vergoed. Die vergoeding moet worden begroot op basis van een vergelijking tussen de feitelijke inkomenssituatie na het ongeval en de hypothetische inkomenssituatie zonder het ongeval (zie par. 2). ${ }^{40}$ Er zijn echter ook auteurs die menen dat deze vergelijkingsmaatstaf losgelaten moet worden, en dat juist gestreefd moet worden naar

36. Benaissa 2015, p. 30 e.v.; R.M.J.T. van Dort, 'Het is een bijzonder kind en dat is-ie!', in: S.D. Lindenbergh, F.Th. Kremer \& J.M. Tromp (red.), Kind en schade: wat nu? Den Haag: PIV 2009, p. 131 e.v.; De Hek 2016. Met deze term wordt gedoeld op informatie die verkregen kan worden door familieachtergrond. Wat doen de ouders, broers en zussen?

37. Reeds aangehaald door: E.M. Schutte, Arbeidsvermogensschade bij kinderen. De benadering van toekomstig verlies aan verdienvermogen na letselschade bij kinderen, Weert: Celsus juridische uitgeverij 2016; E. Schutte, Arbeidsvermogensschade bij kinderen, TLP 2017/85, afl. 4, p. 20-28.

38. EctHR \& Council of Europe/EU Fundamental Rights Agency (FRA), Handbook European non-discrimination law, Straatsburg/Wenen 2010, p. 124, zie fra.europa.eu/en/publication/2011/handbook-european-non-discrimination-law-2011-edition.

39. Bolt, in: GS Schadevergoeding, art. 6:107 BW, aant. 2.15.3.1; Lindenbergh \& Van der Zalm 2015, p. 52-53.

40. Zie bijv. Van Dort 2009 en Janssen 2007. 
herstel van het slachtoffer binnen de ontstane toestand. ${ }^{41}$ Hierna bespreek ik de alternatieve benaderingen in de Nederlandse literatuur en rechtspraak. ${ }^{42}$ De bespreking valt uiteen in vier delen. In het eerste deel bespreek ik alternatieve benaderingen die aansluiten bij de klassieke methode (par. 5.2). Het tweede deel betreft benaderingen die zich meer richten op de toekomst (par. 5.3). In het derde deel komt een volledig abstracte wijze van schadebegroting aan de orde (par. 5.4). In het vierde deel evalueer ik alle alternatieve benaderingen in het licht van het non-discriminatiebeginsel (par. 6).

\subsection{Alternatieve benaderingen die aansluiten bij de klassieke methode}

\subsubsection{Onderscheid tussen interne en externe factoren}

Kolder meent dat het wenselijk is dat het algemene kader voor de vaststelling van de hypothetische situatie zonder ongeval wordt verfijnd. ${ }^{43} \mathrm{Hij}$ acht het noodzakelijk dat de door de Hoge Raad uitgezette lijn als volgt wordt aangepast:

'Ter vaststelling van de hypothetische situatie zónder ongeval moet onderscheid worden gemaakt tussen aspecten gelegen (zuiver) binnen de constitutie van de benadeelde partij en daarbuiten gelegen factoren. ${ }^{44}$

De aspecten die gelegen zijn binnen de constitutie ${ }^{45}$ van een persoon hebben betrekking op zuiver interne factoren van het slachtoffer. Deze factoren zien daarom veelal op de (fysieke en mentale) gezondheid of de medische toestand van de benadeelde en diens persoonlijke kwaliteiten. ${ }^{46}$ De aspecten die daarbuiten zijn gelegen, betreffen over het algemeen omgevingsfactoren, zoals sociaal-maatschappelijke, economische en carrièretechnische aspecten. ${ }^{47}$

Kolder vertrekt vanuit de klassieke benadering en voegt aan de vaststelling van de hypothetische situatie zónder ongeval een novum toe: er zou onderscheid moeten worden gemaakt tussen 'interne' en 'externe' factoren. Met dit onderscheid tracht Kolder licht te werpen op de vraag in hoeverre de rechter bepaalde factoren in aanmerking mag nemen bij de vaststelling van de situatie zonder ongeval. Vanuit het perspectief van een

41. Zie bijv. Nieuwenhuis 2005; A.J. Akkermans, Think rehab!, in: A.J. Akkermans e.a. (red.), (Je) geld of je leven (terug). Vergoeding in natura, Den Haag: Boom juridisch 2015, p. 11-36; M.A. Loth, Achter het stuur in de bus. Over het herstel van autonomie in het aansprakelijkheidsrecht, AV\&S 2016/18, afl. 3, p. 94-100 (hierna: Loth 2016b); F.Th. Kremer, 'Wat nu' in plaats van 'wat anders'?, in: S.D. Lindenbergh, F.Th. Kremer \& J.M. Tromp (red.), Kind en schade: wat nu?, Den Haag: PIV 2009, p. 139-152.

42. Voor eerder onderzoek naar alternatieve benaderingen voor de schadeberekening van arbeidsvermogen, zie Schutte 2016; 2017.

43. Zie A. Kolder, Letselschade: de hypothetische situatie zonder ongeval, TVP 2015, afl. 2, p. 26, waarin de standaardrechtspraak in het kort wordt genoemd. Zie ook par. 3 van deze bijdrage.

44. Kolder 2015, p. 26.

45. Constitutie is het complex van bij de geboorte aanwezige lichamelijke en geestelijke eigenschappen.

46. Kolder 2015, p. 26.

47. Kolder 2015, p. 26. respectvolle bejegening van het slachtoffer alsmede de menselijke waardigheid zouden ten aanzien van de factoren die binnen de constitutie van het slachtoffer zijn gelegen, terughoudendheid en bescheidenheid gepast zijn. ${ }^{48}$ Volgens Kolder moet er een 'concrete aanwijzing' bestaan, alvorens deze factoren ten nadele van het slachtoffer in aanmerking kunnen worden genomen. ${ }^{49}$ Bovendien zou 'voor het afdingen op de persoon van het slachtoffer een "verzwaarde betwistplicht" van de aansprakelijke partij hebben te gelden'. ${ }^{50}$ Dit betekent dat als de aansprakelijke partij de stellingen van het slachtoffer betwist, er hoge eisen moeten worden gesteld aan haar motivering. Met betrekking tot de buiten de constitutie van het slachtoffer gelegen factoren zou de huidige benadering van de Hoge Raad volstaan.

Het door Kolder voorgestane alternatief heeft niet tot doel de problemen rondom de begroting van de arbeidsvermogensschade van jonge kinderen te verhelpen. $\mathrm{Bij}$ toepassing van bovenstaande aanvulling blijft het lastig om voor jonge slachtoffers de hypothetische situatie zonder ongeval vast te stellen. Het toetsingskader voor wat betreft de externe factoren (denk aan sociale factoren) is immers gelijk. Toch is deze visie vanuit gelijkheidsoverwegingen interessant. Met invoering van het bovengenoemde criterium is het mogelijk dat de rechter zorgvuldiger omgaat met de constitutionele kenmerken van slachtoffers. Op die manier zouden de meeste vormen van verboden onderscheid kunnen worden voorkomen. Toch makt deze aanvulling de schadebegroting niet geheel bestand tegen discriminatie. Aangezien er onbeperkt rekening mag worden gehouden met alle sociale factoren aan de kant van de benadeelde, zou er tóch sprake kunnen zijn van verboden onderscheid, namelijk op grond van sociale afkomst als bedoeld in artikel 21 lid 1 EU-Handvest.

\subsubsection{Persoonlijk Modaal Model}

In de overtuiging van Van Dort dient de rechter de schade van jonge slachtoffers op dezelfde wijze te benaderen als die van volwassenen. Dit betekent dat de schadebegroting plaats dient te vinden volgens de beginselen van concrete en volledige schadevergoeding. Van Dort benadrukt dat hiervoor 'elke aanwijzing die iets zegt of kan zeggen over het functioneren van het kind' van belang is. ${ }^{51}$ Als een inschatting moet worden gemaakt van de arbeidsvermogensschade van kinderen, zullen veelal minder refertegegevens beschikbaar zijn. Dit brengt met zich mee dat er minder zekerheid bestaat over de juistheid van aannames. In dat geval rechtvaardigt de jonge leeftijd van het slachtoffer een ruimhartigere benadering van de schade ten gunste van de benadeelde, aldus Van Dort. ${ }^{52}$ De feiten en omstandigheden die als basis kunnen dienen voor de schade-

\footnotetext{
48. Kolder 2015, p. 29.

49. Kolder 2015, p. 33.

50. Kolder 2015, p. 31, met verwijzing naar art. 149 Rv.

51. Van Dort 2009, p. 137. Deze benadering is reeds aangehaald in Schutte $2016 ; 2017$.

52. Van Dort 2009, p. 137.
} 
begroting zouden daarom soepel moeten worden aangenomen. Dit is in lijn met eerdere rechtsspraak van de Hoge Raad.

In gevallen waarin geen of nauwelijks aanknopingspunten zijn voor begroting van het verlies verdienvermogen, zoals bij jonge kinderen, baby's en peuters, zou volgens Van Dort het Persoonlijk Modaal Model (PMM) uitkomst moeten bieden. ${ }^{53}$ In het PMM is de hypothetische situatie zonder ongeval gesteld op een modaal opleidings- en verdienniveau, ${ }^{54}$ met een correctiemogelijkheid indien bijzondere omstandigheden daartoe aanleiding geven. ${ }^{55}$ Voor de inventarisatie van de modale opleidings- en verdienniveaus zou gebruik moeten worden gemaakt van de gegevens van het CBS, opleidingsinstituten, wetenschappelijke onderzoeken enzovoort.

Van het PMM (het basisniveau) kan zowel ten gunste als ten nadele van het slachtoffer worden afgeweken. De bijzondere omstandigheden die afwijking van het standaard-PMM zouden rechtvaardigen, zouden bijvoorbeeld gelegen kunnen zijn in de familiale afkomst, het bijzonder intelligentieniveau van het kind en zijn sportieve of andere vaardigheden. ${ }^{56} \mathrm{Op}$ deze wijze tracht Van Dort in zijn model het persoonlijk karakter van het kind tot uiting te brengen. Het persoonlijke element zou kunnen worden herleid uit het verdienniveau van de gezinsleden van het kind. Komt het kind bijvoorbeeld uit een gezin waarvan de leden in het onderwijs zijn gegaan, dan kan hiervoor het modale inkomen van leraren worden vastgesteld. Een andere optie zou zijn dat het verdienniveau gecategoriseerd wordt naar opleidingsniveau (mbo, hbo, wo), waarna de modale lijn wordt vastgesteld in de beroepsgroep waarin het kind volgens de 'redelijke verwachtingen' terecht had kunnen komen. ${ }^{57}$

Zijn er refertegegevens aanwezig die erop wijzen dat het kind zonder letsel een inkomen onder het modale niveau zou hebben verdiend, dan wordt daar in het PMM ook rekening mee gehouden. Aanwijzingen voor een lager inkomen zouden gelegen kunnen zijn in de medische achtergrond van het kind, zoals een aangeboren ziekte of aandoening. Van Dort benadrukt dat het dan wel moet gaan om 'concrete en overtuigende gegevens', waarbij niet lichtvaardig moet worden afgeweken naar een lager niveau dan het modale inkomen. ${ }^{58}$ De ratio achter dit model is dat jonge kinderen bij wie een referentiekader ontbreekt, in bescherming moeten worden genomen zonder dat zij worden afgerekend op hun jonge leeftijd. ${ }^{59}$

\footnotetext{
53. Van Dort 2009, p. 134.

54. Het modale inkomen is het inkomen dat het meest voorkomt in Nederland, en dus niet het gemiddelde inkomen. Het Centraal Planbureau (CPB) heeft het bruto modale inkomen in 2018 vastgesteld op $€ 37.500$ (inclusief vakantiegeld).

55. Van Dort 2009, p. 134 e.v.; R. Rijnhout \& H.M. Storm, Recensie Kind en schade: wat nu?, TVP 2010, afl. 3, p. 90.

56. Van Dort 2009, p. 135

57. Van Dort 2009, p. 135

58. Van Dort 2009, p. 136.

59. Van Dort 2009, p. 136
}

Dit model biedt praktische handvatten als er geen of nauwelijks aanknopingspunten zijn om het inkomensverlies van jonge kinderen vast te stellen. ${ }^{60}$ Mogelijk laat deze methode ook minder ruimte voor discussie tussen partijen. In dit model schuilt echter volgens mij ook een gebrek. Van Dort hecht in zijn model grote betekenis aan de familiale achtergrond van de benadeelde: deze factor vormt een bijzondere omstandigheid op grond waarvan kan worden afgeweken van het PMM. Dit model zou dan zo kunnen uitwerken, dat de schadevergoeding van de zoon van een stratenmaker lager uitvalt dan de schadevergoeding van de zoon van een tandarts, terwijl de overige omstandigheden van de slachtoffers gelijk zijn. Het in aanmerking nemen van de factor familiale afkomst bij de schadeberekening zou mogelijk verboden onderscheid op grond van sociale afkomst inhouden. Om die reden denk ik dat dit model op het punt van gelijke behandeling tekort zou kunnen schieten.

Een ander kritiekpunt betreft de doelgroep van deze benadering. Het PMM is bedoeld voor jonge kinderen met ernstig letsel. Van Dort laat echter niet blijken welke leeftijdsgrens gehanteerd moet worden. In de praktijk zal dat ook lastig te bepalen zijn. Hoe kan gerechtvaardigd worden dat de arbeidsvermogensschade van een 17 -jarige geheel anders wordt vastgesteld dan die van een 18-jarige? Schutte stelt daarom terecht dat het toepassingsbereik van het PMM uitgebreid moet worden tot slachtoffers van alle leeftijden. ${ }^{61} \mathrm{Zij}$ bepleit een 'glijdende schaal' tussen de traditionele schadebegroting en het PMM. Het aangepaste model werkt zo uit, dat bij hele jonge kinderen bij wie refertegegevens ontbreken, uitgegaan moet worden van een modaal inkomen. Wanneer het slachtoffer ouder is en er wel aanknopingspunten aanwezig zijn, dient het modale inkomen aangepast te worden naar diens persoonlijke omstandigheden. Bij volwassenen zou dat veelal neerkomen op een concrete schadeberekening. ${ }^{62}$

\subsection{Toekomstgerichte visies}

\subsubsection{Introductie}

Hierna zal ik drie toekomstgerichte benaderingen uiteenzetten: de fondsvorming, de 'wat nu?'-aanpak en de herstelgerichte benadering. Deze visies hebben met elkaar gemeen dat zij de vergelijking mét en zónder ongeval loslaten en de pijlen richten op herstel binnen de ontstane toestand.

\subsubsection{Fondsvorming}

De eerste toekomstgerichte benadering is de stuwmeer- of fondsentheorie, ook wel 'het Zwolse model' genoemd naar aanleiding van de uitspraak van de Rechtbank Zwolle van 23 december $1992 .{ }^{63}$ In dit model worden bij jonge slachtoffers met ernstig letsel de uitgangspunten van concrete en volledige

60. In gelijke zin: Schutte 2017.

61. Schutte 2016; 2017

62. Schutte 2016; 2017

63. Rb. Zwolle 23 december 1992, ECLI:NL:RBZWO:1992:AJ6195, VR 1995/203; Van Dort 2009, p. 120; Lindenberg \& Van der Zalm 2015, p. 52-53. 
schadevergoeding verlaten, en komt het verlies van arbeidsvermogen niet voor vergoeding in aanmerking. In plaats daarvan wordt de focus gericht op de resterende bestedingsmogelijkheden van het kind en op zijn door het letsel gewijzigde behoeften. ${ }^{64}$

Deze zienswijze vertrekt vanuit het idee dat het Nederlandse socialezekerheidsstelsel het slachtoffer zal voorzien in zijn dagelijkse onderhoud. ${ }^{65}$ Het fonds dient ter financiering van de extra uitgaven die gemaakt worden om het leven van het slachtoffer te veraangenamen. ${ }^{66}$ De facto komt deze benadering erop neer dat er geen vergelijking meer plaatsvindt tussen de situatie mét en zonder ongeval, maar dat de door het letsel gecreëerde situatie het vertrekpunt vormt voor de te vergoeden schade. ${ }^{67}$

In de rechtspraak is de theorie van fondsvorming drie keer toegepast. ${ }^{68}$ Alle drie de zaken zijn in de literatuur bekritiseerd. ${ }^{69}$ Het standpunt dat bij jonge slachtoffers afgeweken zou moeten worden van de klassieke benadering van schadevergoeding, wordt in de literatuur en rechtspraak gerechtvaardigd met een aantal stellingen. Allereerst zou het verlies van arbeidsvermogen moeilijk concreet te berekenen zijn vanwege het gebrek aan referentiegegevens. ${ }^{70}$ Daarnaast zou bij jonge kinderen met ernstig letsel geen sprake zijn van 'op een enige wijze - normale - terugkeer in de maatschappij'. ${ }^{71}$ Voorts zou het sterk verminderde ziektebesef van het kind een volledige vergoeding in de weg staan. ${ }^{72}$ Bovendien zou het bestedingspatroon wezenlijk anders zijn. ${ }^{73}$ Ten slotte wordt gesteld dat de verzorgingskosten van kinderen aanzienlijk hoger uitvallen dan voor volwassenen. ${ }^{74}$ Deze argumenten zijn zeer omstreden. Voor wat betreft het eerste argument tekenen Rijnhout en Storm - wat mij betreft terecht - aan dat het feit dat de referentiegegevens minimaal zijn of ontbreken, niet betekent dat schadebegroting achterwege moet blijven. ${ }^{75}$ Het zojuist besproken PMM vormt een goed voorbeeld van een benadering die het mogelijk maakt om, door middel van abstrahering van de concrete situatie en hantering van gemiddelde gegevens, de arbeidsvermogensschade van kinderen te berekenen.

64. Van Dort 2009, p. 120; reeds aangehaald door Schutte 2017.

65. J.F. Roth \& J.L. van Schoonhoven, Schade van jeugdigen, in: Handboek personenschade, Deventer: Wolters Kluwer 2015, nr. 3045-12.

66. Van Dort 2009, p. 120 en 125; F.Th. Kremer, Normen bij schade van jonge kinderen, TVP 2002, afl. 4, p. 125-127; Kremer 2009, p. 139-152; Giesen \& Tjittes 2004, p. 73-90.

67. Van Dort 2009, p. 125.

68. GiEA Curaçao 15 januari 1973, NJ 1973/314; Janssen 2007, par. 4.1; Rb. Zutphen 16 februari 1989, rolnr. 1522/85 (Mil/Gregoor) (niet gepubliceerd). Voor de belangrijkste overwegingen, zie Janssen 2007, par. 4.2. Rb. Zwolle 23 december 1992, ECLI:NL:RBZWO: 1992:AJ6195, VR 1995/203

69. Zie bijv. Janssen 2007.

70. Hartlief 2005, p. 167-168; 2009, p. 523-542; Giesen \& Tjittes 2004, p. 87; Nieuwenhuis 2005, p. 95; Kremer 2009, p. 140 e.v.

71. Kremer 2002, p. 127; 2009, p. 144.

72. Van Dort 2009, p. 127. GiEA Curaçao 15 januari 1973, NJ 1973/314 en Rb. Zutphen 16 februari 1989, rolnr. 1522/85 (Mill/Gregoor).

73. Kremer 2002, p. 127; 2009, p. 144.

74. Kremer 2002, p. 127; 2009, p. 144.

75. Rijnhout \& Storm 2010, p. 91.
Ook het tweede argument kan worden bediscussieerd. Dit argument geldt namelijk evenzeer voor volwassen slachtoffers. Bij deze groep kan het ook zo zijn dat 'normale' terugkeer in de maatschappij niet meer mogelijk is, maar bij hen wordt het inkomensverlies concreet berekend. Mijns inziens hoort dat bij jonge slachtoffers niet anders te zijn. Een rechtvaardiging voor een afwijkende behandeling van jonge kinderen enerzijds en volwassenen anderzijds ontbreekt. Met betrekking tot het derde argument, te weten dat het verminderde ziektebesef deze benadering zou rechtvaardigen, wordt gesteld dat besef van de eigen situatie geen relevante factor is voor de vaststelling van de materiële schade. ${ }^{76}$ De gedachte 'wat niet weet, wat niet deert' getuigt bovendien van een onsympathieke houding. ${ }^{77}$ Ook zou het willekeurig zijn om bij volwassenen geen rekening te houden met het verminderde ziektebesef, terwijl dit wel in aanmerking wordt genomen bij de bepaling van de schade van het kind. Ten aanzien van het veranderde bestedingspatroon wordt in de literatuur opgemerkt dat dit aspect in beginsel losstaat van het verlies van arbeidsvermogen. ${ }^{78} \mathrm{Bij}$ slachtoffers - jong of oud - is het veranderde bestedingspatroon inherent aan het opgelopen letsel. Dat er schade bestaat, is een vaststaand gegeven, hoe de uitgekeerde schade moet worden besteed, is aan het slachtoffer. Dat het slachtoffer beperkingen ondervindt om zijn vergoeding conform het 'normale' bestedingspatroon te besteden, betekent niet dat hij daarom geen recht meer zou hebben op volledige vergoeding van zijn inkomensverlies.

\subsubsection{De 'wat nu?'-variant}

Vertrekkend vanuit de kritiek op fondsvorming, introduceert Kremer de 'wat nu?'-aanpak. ${ }^{79}$ Dit alternatief vertoont gelijkenis met de fondsentheorie, en houdt in dat gekeken moet worden naar de situatie van het slachtoffer met letsel om hem 'voor nu en voor de toekomst een zo aangenaam en menswaardig mogelijk bestaan te geven met goede verzorging. ${ }^{80} \mathrm{De}$ omvang van de schadevergoeding wordt derhalve bepaald door de behoeften van het slachtoffer. Kremer gaat hierbij uit van een maximale leeftijdsgrens van 16 jaar. De benadering zou moeten worden toegepast ingeval er geen (resterende) verdiencapaciteit meer is. Dit model wijkt in één belangrijk opzicht af van de fondsentheorie, namelijk dat het alleen ziet op de vergoeding van materiële schade. Volgens Kremer is 'vermenging van materiële schade en smartengeld - zoals dat wel bij fondsvorming gebeurt - (...) niet zuiver, omdat deze twee verschillende soorten schade ook afzonderlijk van elkaar vergoed moeten worden'. ${ }^{81}$ In zoverre is de 'wat nu?'-aanpak mijns inziens

\footnotetext{
76. Janssen 2007, par. 1 en 4.1; Van Dort 2009, p. 129, waarin gesteld wordt dat bij fondsvorming een behoeftigheidselement (in de zin van art. 6:108 lid $1 \mathrm{BW}$ ) wordt geïntroduceerd.

77. Van Dort 2009, p. 129.

78. Rijnhout \& Storm 2010, p. 91.

79. Kremer 2002, p. 125 e.v.; F.Th. Kremer, Berekening van (toekomst)schade van ernstig gewonde jonge kinderen, in: F.T. Oldenhuis (red.), Toekomstschade: wat is een mensenleven waard?, Den Haag: Boom Juridische uitgevers 2008, p. 37-46; Kremer 2009, p. 148 e.v.

80. Van Dort 2009, p. 142.

81. Kremer 2009, p. 148-149.
} 
een verbetering van de fondsentheorie. Zoals Janssen eerder heeft opgemerkt, wordt bij vermenging van deze schadeposten het zicht op de samenstelling van de schadevergoeding ontnomen. ${ }^{82}$

De 'wat nu?'-aanpak verschilt voor het overige niet wezenlijk van de fondsentheorie. De bovenstaande kritiekpunten die gericht zijn op de fondsentheorie gelden daarom evenzeer voor dit alternatief.

\subsubsection{Herstelgerichte benadering}

Een alternatieve benadering die op steeds meer steun kan rekenen, is de herstelgerichte benadering, ook wel rehab-benadering. ${ }^{83}$ De grondgedachte is vergelijkbaar met die van de 'wat nu?'-aanpak, maar het toepassingsgebied is breder. Anders dan de 'wat nu?'-aanpak geldt de herstelgerichte benadering voor de afwikkeling van alle letselschadegevallen. ${ }^{84}$ In dit alternatief staat het herstel van het slachtoffer voorop en komt schadevergoeding op de tweede plaats. ${ }^{85}$ In de traditionele benadering ligt de nadruk op schadevergoeding en is om de redelijke toekomst te bepalen de blik gericht op het verleden. Dit zou het herstel van het slachtoffer belemmeren. ${ }^{86}$ In deze benadering wordt daarom de vergelijking mét en zónder ongeval losgelaten, en is het vizier gericht op herstel binnen de ontstane toestand. In dat kader wordt 'herstel' ruim uitgelegd. Het gaat daarbij om herstel op medisch gebied, maar evenzeer op praktisch, psychologisch, emotioneel en sociaal gebied. ${ }^{87}$ In de eerste plaats gaat het bij deze benadering 'om het zoeken naar mogelijkheden tot zelfontplooiing, het herstel van de autonomie, het zoeken naar capaciteiten van de benadeelde die wél [of: méér; IK] benut kunnen worden, kortom, naar wat nog wél mogelijk is ${ }^{88} \mathrm{Om}$ deze doelstellingen te bereiken zouden de 'traditionele coördinaten van het aansprakelijkheidsrecht' moeten worden verlaten. ${ }^{89}$ Dit wordt nodig geacht, omdat de huidige benadering op verschillende punten 'knelt'. ${ }^{90}$ Boven-

82. Ook kritisch hierover: Janssen 2007, par. 4.1; Van Dort 2009, p. 128.

83. De gedachte is oorspronkelijk afkomstig van Nieuwenhuis 2005, p. 94. Zie ook Akkermans 2015, p. 11 e.v.; Loth 2016b, p. 94-100; T. Hartlief, Waar ligt de toekomst van het personenschaderecht?, NJB 2015/2003, afl. 40, p. 2791. Hartlief signaleert de 'massieve belangstelling' voor een benadering waarin herstel vooropstaat.

84. Zie bijv. Akkermans 2015, p. 11-36; G. van Dijck, Naar een nieuw schadevereiste in het aansprakelijkheidsrecht, NJB 2016/1127, afl. 23, p. 1608-1616; G. van Dijck, Emotionele belangen en het aansprakelijkheidsrecht, NJB 2015/1787, afl. 36, p. 2530-2536; Hartlief 2015, p. 2791; Loth 2016b, p. 94-100.

85. Akkermans 2015, p. 16-18; Loth 2016b, p. 97-98; 2016a, p. 33-73; Hartlief 2015, p. 2791; S.D. Lindenbergh, Herstel bij letsel. Over de juridische fundering van verplichtingen in herstel, in: G.R. de Groot e.a. (red.), Kritiek op recht, Deventer: Kluwer 2014, p. 239-252 (hierna: Lindenbergh 2014b).

86. Akkermans 2015, p. 19.

87. Akkermans 2015, p. 13. Aangehaald door Hartlief 2015, p. 2791 en Van Dijck 2016, p. 1612.

88. Van Dijck 2016, p. 1612; Loth 2016a, p. 30.

89. Nieuwenhuis 2005, p. 93; Loth 2016b, p. 94-95 en 99-100.

90. Van Dijck 2016, p. 1611. In zijn bijdrage stelt Van Dijck dat de huidige schadevereiste problematisch is waar het gaat om immateriële schade, niet-financiële belangen en materiële schade, waarvan het bepalen van de hoogte speculatief is. dien zou een benadering waarin het accent verschuift van primair schadevergoeding naar primair herstel, beter aansluiten bij de doelstellingen van het aansprakelijkheidsrecht. ${ }^{91}$ De theoretische fundering voor een dergelijke visie wordt gevonden in de elementen van distributieve rechtvaardigheid. Pas wanneer het voorkomen, beperken of herstellen van de schade niet meer mogelijk is, zou schadevergoeding aangewezen zijn. ${ }^{92}$

\subsubsection{Commentaar op toekomstgerichte maatstaf}

In de literatuur wordt de meerwaarde van een benadering die 'slachtoffers laat loskomen van het verleden en juist toekomst geeft' meer en meer gewaardeerd. ${ }^{93}$ Het voordeel van een dergelijke benadering is evident: het herstel van het slachtoffer wordt bevorderd. Daartegenover staat een belangrijk bezwaar, namelijk dat het schadebegrip bij toekomstgerichte visies lastig hanteerbaar is. Voor het bepalen van de schade zou de huidige vergelijkingsmaatstaf tussen de ontstane situatie en de hypothetische situatie volledig moeten worden losgelaten. Omdat de schadevergoeding wordt geschat op basis van subjectieve 'behoeften' van het slachtoffer, kan de schade niet scherp worden afgebakend. ${ }^{94}$ Het risico van een dergelijk schadebegrip is 'onbegrensde aansprakelijkheid en toenemende flexibiliteit (complexiteit) van schadebegroting. ${ }^{95}$

De fondsentheorie, de 'wat nu?'-aanpak en de herstelgerichte benadering zouden wellicht meer in lijn zijn met gelijkebehandelingswetgeving dan met de klassieke methode van schadebegroting. Dit hangt vooral af van de uitwerking van deze modellen, en meer specifiek van de vraag hoe de behoeften van het slachtoffer worden vastgesteld. Als de behoeften worden bepaald op basis van bijvoorbeeld een modaal bestedingspatroon of 'maatman', ${ }^{96}$ dan zouden discriminatoire factoren zoals geslacht, ras en etniciteit geen rol meer spelen. De factor leeftijd is daarentegen wel relevant in de eerste twee benaderingen. In dat opzicht zou bij de schadebegroting van jonge kinderen sprake kunnen zijn van onderscheid op grond van leeftijd.

\subsection{Volledig abstracte methode}

De laatste alternatieve benadering is de volledig abstracte schadebegroting, zoals voorgesteld door Janssen. ${ }^{97}$ Dit alternatief zou gelden voor baby's en peuters die als gevolg van ernstig hersenletsel in 'de knop' van hun ontwikkeling zijn gebroken. ${ }^{98}$ Daarbij wordt een leeftijdsgrens van 4 jaar gehanteerd.

91. Loth 2016b, p. 100

92. Loth 2016b, p. 97-98. Zie ook Loth 2016a, p. 33-73; Lindenbergh 2014b, p. 239-252.

93. Hartlief 2015, p. 2791.

94. K.J.O. Jansen, Het schadebegrip in de eenentwintigste eeuw, WPNR $2017 / 71333$, par. 2.3. Jansen stelt dat wanneer de behoefte van het slachtoffer in de sleutel van het autonomiebeginsel wordt geplaatst, zoals voorgesteld door Loth (2016a), deze enigszins geobjectiveerd kan worden; een scherpe afbakening echter lijkt daarin niet besloten te liggen.

95. Van Dijck 2016, p. 1615. In gelijke zin: Jansen 2017, par. 2.3.

96. Loth 2014, p. 117-118; Loth 2016a, p. 33-73, waarin de 'maatman' als alternatief wordt voorgesteld.

97. Janssen 2007.

98. Janssen 2007, par. 1. 
Voor deze groep zou afwijking van de klassieke benadering van schadebegroting gerechtvaardigd zijn, omdat geen objectief oordeel kan worden gegeven over hun sociale, emotionele en cognitieve vermogens en ontwikkeling. ${ }^{99}$ Volgens Janssen kan de klassieke benadering van schadeberekening pas de volledig abstracte methode vervangen als er voldoende aanknopingspunten zijn voor een betrouwbare voorspelling van de hypothetische toekomstontwikkelingen van de benadeelde. Hoewel Janssen dit punt niet expliceert, kan mijns inziens uit zijn betoog worden afgeleid dat hij veronderstelt dat dergelijke aanknopingspunten vrijwel nooit aanwezig zullen zijn bij kinderen tot 4 jaar. Van Dort stelt dan ook dat dit model geen enkele ruimte laat voor verdere differentiatie naar de bijzondere of persoonlijke omstandigheden van de kinderen. ${ }^{100}$

In deze benadering wordt het verlies van arbeidsvermogen berekend aan de hand van het gemiddelde inkomen uit arbeid in Nederland. ${ }^{101}$ De inkomensnorm is de uitkomst van het totale nationale inkomen uit arbeid, gedeeld door de totale potentiële beroepsbevolking. ${ }^{102}$ Janssen stelt dat de ondergrens van de beroepsbevolking gesteld zou kunnen worden op de leerplichtige leeftijd, zodat aangenomen kan worden dat vanaf dat moment het werkzame bestaan aanvangt. ${ }^{103}$ In het kader van de praktische hanteerbaarheid van deze optie zou tevens moeten worden geabstraheerd van andere aangelegenheden. Hierbij kan worden gedacht aan de vermogensrechtelijke consequenties van een hypothetische samenleving met een partner en de hypothetische kinderwens. ${ }^{104}$

Deze schadebegrotingswijze heeft een duidelijk kader aan de hand waarvan de arbeidsvermogensschade van jonge kinderen wordt vastgesteld. Omdat de schade eenvoudiger kan worden bepaald, is het mogelijk dat deze benadering leidt tot kortere procedures. Voorts zou hantering van het criterium van 'gemiddeld inkomen' voorkomen dat er onderscheid wordt gemaakt op grond van geslacht, ras en andere constitutionele kenmerken. Alle jonge slachtoffers met ernstig hersenletsel zouden namelijk een vergelijkbare uitkering krijgen. Omdat de schadebegroting van jonge kinderen afwijkt van die van volwassen slachtoffers zou deze benadering wel onderscheid op grond van leeftijd opleveren. Daarnaast stelt van Dort een ander kritiekpunt aan de orde. Volgens hem wordt het jonge kind in deze benadering tekortgedaan. ${ }^{105} \mathrm{Hij}$ stelt dat de werkzame groep, op basis waarvan het gemiddelde inkomen wordt bepaald, te breed is afgebakend. Onder de beroepsbevolking vallen immers ook personen die weloverwogen dan wel gedwongen niet deelnemen aan het arbeidsproces. Hoe

99. Janssen 2007, par. 1.

100. Van Dort 2009, p. 135.

101. Janssen 2007, par. 6. Het begrip 'gemiddeld inkomen' oftewel het 'gemiddelde nationale loon' komt uit de Nederlandse inkomenspolitiek. Het gemiddelde inkomen per arbeidsjaar wordt vastgesteld door het $\mathrm{CPB}$.

102. Janssen 2007, par. 6; Van Dort 2009, p. 134-135.

103. Janssen 2007, par. 6

104. Janssen 2007, par. 6

105. Van Dort 2009, p. 135. meer personen onder de potentiële beroepsbevolking vallen, hoe lager het inkomen dat resteert als verdienniveau zonder letsel. ${ }^{106} \mathrm{Hij}$ vindt het onterecht dat jonge kinderen de algemene 'kwade kansen' van het niet deelnemen aan het arbeidsproces toebedeeld krijgen, terwijl dit bij volwassenen marginaal gebeurt. ${ }^{107}$

\section{Evaluatie}

\subsection{Startpunt: restitutio in integrum en kindschade}

De genoemde alternatieven hebben niet altijd dezelfde doelgroep. Het alternatief van Kolder en de herstelgerichte benadering worden voorgesteld voor letselschadeslachtoffers in het algemeen. De overige benaderingen zijn wel specifiek bedoeld voor jonge slachtoffers. De alternatieven verschillen ook in een ander opzicht van elkaar. Aan de ene kant staan de modellen die vasthouden aan de grondbeginselen van het schadevergoedingsrecht, aan de andere staan de benaderingen die deze juist verlaten. Belangrijk zijn dus de vragen of het beginsel van restitutio in integrum leidend zou moeten blijven, en of de positie van jonge slachtoffers een alternatieve benadering hiervoor kan rechtvaardigen. ${ }^{108}$

Wat de eerste vraag betreft ben ik van mening dat het uitgangspunt van restitutio in integrum gehandhaafd moet blijven. Dit uitgangspunt biedt over het algemeen een duidelijk kader aan de hand waarvan de schade kan worden vastgesteld. In de toekomstgerichte benaderingen ontbreekt vooralsnog een transparant kader aan de hand waarvan de behoeften van het slachtoffer dienen te worden vastgesteld. ${ }^{109}$ Bovendien kan het doel van deze benaderingen ook met behulp van het huidige kader worden bereikt. Het wettelijke stelsel bevat voldoende mogelijkheden voor het verstrekken van dienstverlening die primair gericht is op de behoeften van het slachtoffer. Deze mogelijkheden zouden daarom in de praktijk nader moeten worden verkend door de belangenbehartigers van het slachtoffer.

Met betrekking tot de tweede vraag bestaat er mijns inziens geen rechtvaardiging om de arbeidsvermogensschade van jonge slachtoffers wezenlijk anders te benaderen dan die van oudere slachtoffers. Dit betekent dat ook bij jonge slachtoffers in beginsel uitgegaan moet worden van concrete en volledige schadebegroting. Het probleem dat de hypothetische vergelijking van de situatie met en zonder ongeval bij jonge kinderen lastig te bepalen is, vormt geen rechtvaardiging om af te stappen van deze beginselen. Artikel 6:97 van het Burgerlijk Wetboek (BW) biedt immers mogelijkheden om de hanteerbaarheid van het schadebegrip te vergroten. De problemen rondom de schadebegroting van jonge kinderen zouden kunnen

\footnotetext{
106. Van Dort 2009, p. 135.

107. Van Dort 2009, p. 135

108. Deze vragen zijn opgeworpen door Rijnhout \& Storm 2010, p. 92. Reeds aangehaald door Schutte 2017.

109. Bedoeld wordt de fondsvorming, de 'wat nu?'-aanpak en de herstelgerichte benadering.
} 
worden opgelost door te abstraheren van de persoonlijke omstandigheden en eigenschappen van de concrete benadeelde.

De hierboven besproken benaderingen van fondsvorming, de 'wat nu?'-aanpak en de herstelgerichte benadering stuiten op verschillende bezwaren, waardoor ik voor nu geen voorstander ben van deze alternatieven. Allereerst is het lastig om vast te stellen wat nodig is voor de ontplooiing van het slachtoffer, daarvoor ontbreekt er immers een duidelijk kader. Bovendien lijken deze benaderingen zich moeilijk te verenigen met het uitgangspunt van volledige schadevergoeding, dat ik als uitgangspunt blijf nemen. Een adequate schadevergoeding is niet gelijk aan een volledige schadevergoeding. De fondsentheorie en de 'wat nu?'-benadering, die beide een onderscheid maken bij de schadebegroting tussen kinderen en volwassenen, zouden daarnaast strijdig kunnen zijn met het Europees Verdrag tot bescherming van de rechten van de mens en de fundamentele vrijheden (EVRM) ${ }^{110}$ en verschillende internationale verdragen. ${ }^{111}$ Een en ander hangt af van de uitwerking, maar die is, zoals gezegd, nog onvoldoende duidelijk.

De volledig abstracte methode verlaat ook de uitgangspunten van het schadevergoedingsrecht, waardoor deze hetzelfde lot moet delen als de hiervoor genoemde benaderingen. Het door Kolder gemaakte onderscheid tussen externe en interne factoren relativeert een belangrijk knelpunt, namelijk de discriminatoire uitwerking van het schadevergoedingsrecht. Omdat dit criterium van toepassing is op slachtoffers in alle leeftijdscategorieën, bestaat er geen onderscheid op grond van leeftijd. Wel bestaat er ruimte voor onderscheid op grond van de sociaal-maatschappelijke status van het kind. Dit kan strijd opleveren met het non-discriminatiebeginsel. Een ander gebrek van deze benadering is dat zij niet écht een uitkomst biedt voor de schadebegroting van jonge kinderen. Dit tekort wordt opgevangen door het Persoonlijk Modaal Model van Van Dort. Deze benadering biedt een oplossing voor het geval dat er geen of onvoldoende refertegegevens aanwezig zijn. Bovendien is dit model verenigbaar met de beginselen van concrete en volledige schadevergoeding. In deze benadering bestaat er echter ruimte voor onderscheid naar de leeftijd en de sociale afkomst van het slachtoffer. Om die reden is ook deze benadering wellicht niet geheel in lijn met gelijkebehandelingswetgeving.

110. Art. 1 van het Eerste Aanvullende Protocol EVRM. Zie meer hierover J.F.M. Janssen, 'De invloed van artikel 1 van het eerste aanvullende protocol EVRM op het Nederlandse recht', in: Rechtseenheid en vermogensrecht, E.M. Meijers-instituut, Deel 102, Deventer: Kluwer 2005, p. 342 e.v.; Janssen 2007 , p. 99-113.

111. Art. 27 lid 4 IVRK en art. 7 VPRH. Zie meer hierover A.F. CollignonSmit Sibbinga \& S.V. Mewa, Fundamentele rechten in de personenschadepraktijk, L\&S 2011/03, afl. 1, p. 9-17; S.V. Mewa, Enkele bijzondere aspecten bij de afwikkeling van schade van minderjarigen - een rechtvaardiger oplossing door een mentaliteitsverandering?, in: W. TonkensGerkma (red.), Letselschade in een breed perspectief, Den Haag: Sdu Uitgevers 2011, p. 50-54.

\subsection{Toetsingskader en het Persoonlijk Modaal Model}

2.0

$\mathrm{Na}$ bestudering van de alternatieve modellen kan worden geconcludeerd dat het PMM en het onderscheid aangebracht door Kolder het meest tegemoetkomen aan de bezwaren van de huidige benadering. Toch zouden ook deze benaderingen vanuit het oogpunt van gelijke behandeling een aantal aanpassingen moeten ondergaan. Om te beginnen zou de aanvulling van Kolder verder moeten worden gespecificeerd, in die zin dat er onderscheid moet worden gemaakt tussen vier categorieën persoonlijke kenmerken, namelijk:

1. interne factoren die zien op de medische toestand van het slachtoffer en diens persoonlijke kwaliteiten;

2. interne factoren op basis waarvan het wettelijk verboden is om onderscheid te maken;

3. externe factoren die betrekking hebben op de sociale afkomst van het slachtoffer;

4. overige externe factoren.

De grondgedachte van Kolder blijft deels gehandhaafd. Voor de interne aspecten die gerelateerd zijn aan de (fysieke en mentale) gezondheid van het slachtoffer en diens persoonlijke kwaliteiten, zou moeten gelden dat de rechter deze factoren terughoudend in beschouwing moet nemen. ${ }^{12}$ Alleen als er concrete aanwijzingen zijn, moet de schadevergoeding naar beneden worden bijgesteld. Op deze manier wordt het slachtoffer met meer respect behandeld en doet het schadevergoedingsrecht meer recht aan de menselijke waardigheid. Een terughoudende benadering is ook in lijn met de rechtspraak van de Hoge Raad. ${ }^{113}$

De tweede categorie wordt gevormd door de aspecten binnen de constitutie van een slachtoffer, op grond waarvan het wettelijk verboden is om onderscheid te maken. Hieronder vallen bijvoorbeeld de factoren geslacht, ras, godsdienst of overtuiging en seksuele gerichtheid. Gelet op het fundamentele karakter van het beginsel van non-discriminatie zou de rechter deze factoren buiten beschouwing moeten laten bij de schadeberekening.

De externe factoren zouden in mijn ogen moeten worden ondergebracht in twee aparte klassen. De eerste klasse ziet op factoren die betrekking hebben op de sociale achtergrond van de benadeelde. Om ongeoorloofd onderscheid naar sociale afkomst te voorkomen zou de rechter de familiale afkomst van de benadeelde niet in aanmerking moeten nemen bij de scha-

112. Kolder 2015 , p. 26

113. Kolder 2015 , p. 30 . 'Uit een nadere analyse van de relevante rechtspraak valt te destilleren dat in relatie tot "de persoon" van het slachtoffer in beginsel enkel in een drietal gevallen (ook) zónder ongeval duurzame (arbeids) uitval wordt aangenomen - dan wel dat daarnaar (nader) specifiek (medisch) onderzoek wordt gelast.' Dit zijn de zogeheten 'Vermaat/ Staat-gevallen' (HR 2 februari 1990, NJ 1991/292), de 'Coronaire trombose-gevallen' (HR 21 maart 1975, NJ 1975/372) en ten slotte het geval waarin het slachtoffer reeds voorafgaande aan het ongeval met (serieuze) gezondheidsproblematiek had te kampen. In de voornoemde gevallen heeft de Hoge Raad ook arbeidsuitval zónder ongeval aangenomen, omdat daar feitelijk concrete aanwijzingen voor waren. 


\section{Figur 1 Toetsingskader voor de vaststelling van de hypothetische situatie}

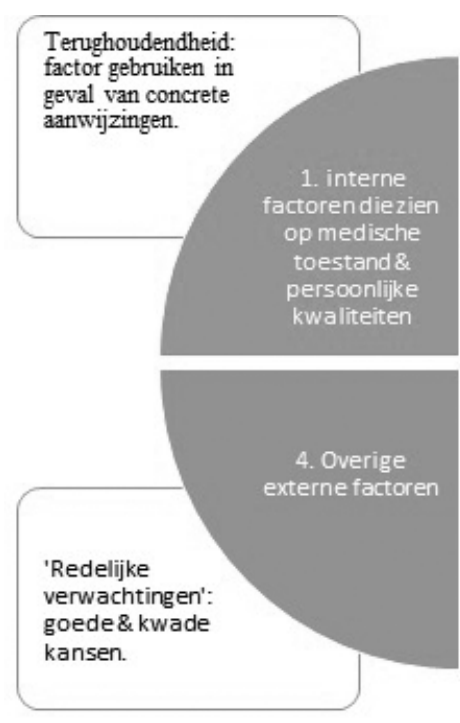

devaststelling. De tweede klasse behelst de overige externe omstandigheden. Hierbij kan worden gedacht aan sociaaleconomische ontwikkelingen, zoals: 'een toename van het aantal ZZP'ers, kortere dienstverbanden, de aanhoudende economische krimp, de verhoging van de pensioenleeftijd, de lage rentestand en de verhoging van pensioenpremies/verlaging van pensioenaanspraken'. ${ }^{114}$ Daarnaast kan worden gedacht aan de carrièretechnische aspecten van het slachtoffer. Hieronder zouden bijvoorbeeld de doorgroeimogelijkheden en eventuele urenuitbreidingen van het slachtoffer kunnen vallen. Voor deze vierde categorie zou de traditionele benadering van de inschatting van de redelijke verwachting moeten gelden, zoals voorgesteld door Kolder. ${ }^{115}$ Onderscheid naar deze factoren is niet expliciet verboden onder de Grondwet of internationale verdragen. Het ligt daarom voor de hand om bij deze factoren geen terughoudendheid van de rechter te vereisen.

Als de hypothetische situatie voor alle letselslachtoffers wordt vastgesteld volgens het in figuur 1 gegeven toetsingskader, is het mogelijk dat de discriminatoire uitwerking van het schadevergoedingsrecht in belangrijke mate wordt beperkt. Hiermee zou de rechter de hypothetische situatie zonder ongeval kunnen reconstrueren.

Om de problematiek rondom de schadevaststelling van kinderen het hoofd te bieden, zou daarnaast ook een meer abstracte benadering moeten worden ingevoerd. Het PMM biedt praktische handvatten voor het geval waarin weinig of geen aanknopingspunten kunnen worden gevonden. Een beperking van dit model is dat de sociale afkomst van het slachtoffer in deze visie een belangrijke rol kan spelen. Vanuit de optiek van gelijke behandeling is dit model derhalve niet optimaal. Het

114. L.C. Dufour \& E.F.E. Palmen, De invloed van sociaaleconomische ontwikkelingen op de begroting van verlies arbeidsvermogensschade, PIVBulletin oktober 2013, p. 10-15. Volgens Dufour en Palmen zijn dit de ontwikkelingen die zich sinds 2000 in toenemende mate voordoen.

115. Kolder 2015, p. 33.

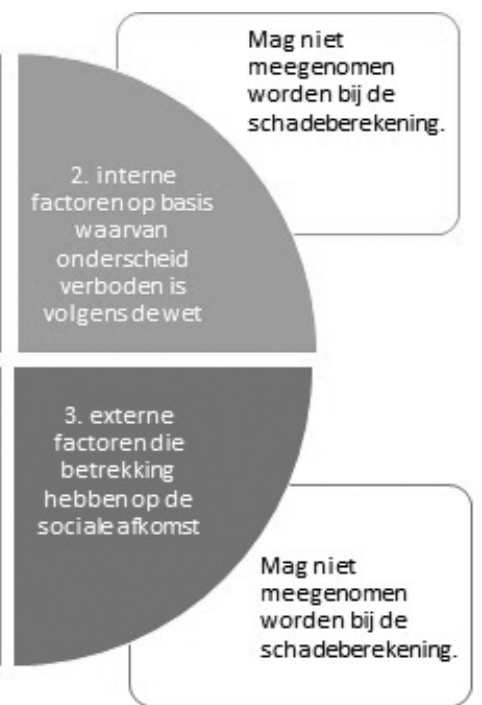

PMM zou daarom moeten worden aangepast, in die zin dat de familiale afkomst van het slachtoffer geen rol meer mag spelen bij de schadeberekening. Daarnaast zou het toepassingsbereik van het model moeten worden uitgebreid tot slachtoffers van alle leeftijden zoals voorgesteld door Schutte. Dit om leeftijdsdiscriminatie te voorkomen. Het Persoonlijk Modaal Model 2.0 zou als volgt uitwerken. Voor hele jonge kinderen (baby's en peuters) zonder refertegegevens zou de hypothetische situatie zónder ongeval moeten worden gesteld op een modaal opleidings- en verdienniveau. Wanneer het kind ouder is en er voldoende aanknopingspunten zijn, zou zijn PMM naar beneden of naar boven kunnen worden bijgesteld. Bij de vaststelling van het hypothetische verdienvermogen zou de rechter gebruik kunnen maken van het hierboven weergegeven toetsingskader. Bij volwassen slachtoffers geldt in beginsel ook het modale inkomen als basis, maar zullen er veeleer genoeg aanknopingspunten aanwezig zijn, waardoor een concrete schadebegroting mogelijk wordt.

\section{Conclusie}

De rechter heeft op grond van het Nederlandse schadevergoedingsrecht de ruimte om bij de begroting van arbeidsvermogensschade te differentiëren naar alle persoonlijke kenmerken van het slachtoffer. Dit geldt ook bij de schadebegroting van jonge kinderen. Dit uitgangspunt kan op gespannen voet komen te staan met gelijkebehandelingswetgeving. Volgens de hogere normen, zoals neergelegd in de Grondwet en internationale verdragen, is het immers verboden om onderscheid te maken ten aanzien van bepaalde persoonlijke eigenschappen van het slachtoffer. Naast de discriminatoire uitwerking van het Nederlandse schadevergoedingsrecht zijn er ook andere knelpunten gesignaleerd. De huidige benadering van de berekening van verlies van het arbeidsvermogen wordt als lastig ervaren, omdat die zeer speculatief zou zijn. Tevens zou deze benadering (te) veel ruimte bieden voor discussies tussen partijen. In deze bijdrage heb ik gezocht naar alternatieven die de 
bezwaren tegen de huidige wijze van schadebegroting kunnen beperken.

Uit de voorgaande analyse kan worden geconcludeerd dat de alternatieve benaderingen niet in staat zijn om de knelpunten bij de huidige wijze van schadeberekening (volledig) weg te nemen. Om dit te bereiken dienen zij in bepaalde opzichten te worden aangepast, zonder dat er afstand hoeft te worden gedaan van de grondbeginselen van het aansprakelijkheidsrecht. Aangezien de huidige benadering discriminatoir kan uitwerken, dient er allereerst een algemeen toetsingskader te worden ontworpen, aan de hand waarvan de rechter de hypothetische situatie kan vaststellen. Dit kader zou naar mijn mening moeten worden aangestuurd door het beginsel van non-discriminatie. In de vorige paragraaf heb ik gepoogd hier een voorzet voor te geven. Het ligt voor de hand dat met de invoering van een dergelijk kader elke vorm van verboden onderscheid uitgebannen kan worden.

De problemen rondom de schadeberekening van jonge kinderen kunnen in belangrijke mate worden beperkt door de invoering van het PMM 2.0. Dit is het model van Van Dort met twee belangrijke aanpassingen. Allereerst mag de familiale afkomst van het slachtoffer geen bijzondere omstandigheid vormen op grond waarvan kan worden afgeweken van de modale inkomenslijn. Daarnaast behoort het toepassingsbereik te worden uitgebreid naar alle letselslachtoffers. Dit aangepaste model kan ervoor zorgen dat gelijke behandeling in het schadevergoedingsrecht wordt bevorderd. Deze benadering is verenigbaar met de huidige uitgangspunten van het schadevergoedingsrecht. $\mathrm{Zij}$ zal daarom eenvoudig kunnen worden ingepast in het huidige systeem. Het voordeel van het PMM is dat het een transparant uitgangspunt biedt voor jonge kinderen, bij wie een referentiekader ontbreekt. Dit kan de eenvormigheid van de rechtspraak ten goede komen. Daarnaast kan deze benadering arbitraire beslissingen terugdringen. Het uitgangspunt van een modaal inkomen biedt ook minder ruimte voor discussies tussen procespartijen. Wanneer het kind wat ouder is, biedt dit model de rechter de ruimte om de schade te begroten aan de hand van de concrete omstandigheden van het kind. In dit model zal dus naarmate er meer aanknopingspunten te vinden zijn, het verschil met de klassieke benadering kleiner worden. Een ander voordeel van deze benadering is dat zij verenigbaar is met het beginsel van gelijke behandeling. Bij de vaststelling van het modale opleidings- en verdienniveau spelen constitutionele kenmerken immers geen rol. 